\title{
Hot spots for diversity of Magnaporthe oryzae physiological races in irrigated rice fields in Brazil
}

\author{
Justino José Dias Neto(1), Gil Rodrigues dos Santos(1), Liamar Maria dos Anjos ${ }^{(1)}$, \\ Paulo Hideo Nakano Rangel ${ }^{(2)}$ and Marcio Elias Ferreira(3)
}

\begin{abstract}
(1)Universidade Federal do Tocantins, Caixa Postal 66, CEP 77410-000 Gurupi, TO, Brazil. E-mail: jjnetodias@uft.edu.br, gilrsan@uft.edu.br, liamar@uft.edu.br (2)Embrapa Arroz e Feijão, Caixa Postal 179, CEP 75375-000 Santo Antonio de Goiás, GO, Brazil. E-mail: phrangel@cnpaf.embrapa.br ${ }^{(3)}$ Embrapa Recursos Genéticos e Biotecnologia, Laboratório de Genética, Caixa Postal 02372, CEP 70770-900 Brasília, DF, Brazil. E-mail: ferreira@cernagen.embrapa.br
\end{abstract}

\begin{abstract}
The objective of this work was to evaluate the Magnaporthe oryzae pathotype diversity in new commercial irrigated rice fields in the Araguaia River Valley, state of Tocantins, Brazil. The causal agent of rice blast has heavily affected rice production in the region. Despite the efforts of breeding programs, blast resistance breakdown has been recorded shortly after the release of new resistant cultivars developed for the region. Among the causes of resistance breakage is the capacity of the fungus to rapidly develop new pathotypes. A sample of $479 \mathrm{M}$. oryzae monosporic isolates was obtained and tested using the international rice blast differential set. Isolate collections were made in small areas designed as trap nurseries and in scattered sites in their vicinity. Analysis of 250 M. oryzae isolates from three trap nurseries indicated the presence of 45 international $M$. oryzae races belonging to seven pathotype groups (IA-IG). In the isolates tested, $61 \mathrm{M}$. oryzae pathotypes belonging to all but the IH group were detected. The new areas of irrigated rice in the Araguaia River Valley have the highest diversity of M. oryzae pathotypes reported so far in Brazil.
\end{abstract}

Index terms: Pyricularia, pathogenicity, pathotype, race.

\section{Alta diversidade de raças fisiológicas de Magnaporthe oryzae em áreas de arroz irrigado em Tocantins, Brasil}

\begin{abstract}
Resumo - O objetivo deste trabalho foi avaliar a diversidade de patótipos de Magnaporthe oryzae em novas áreas comerciais de arroz irrigado instaladas no Vale do Rio Araguaia, Estado do Tocantins, Brasil. A produção de arroz nessa região vem sendo significativamente afetada pelo agente causal da brusone do arroz. Apesar dos esforços de programas de melhoramento genético, a ocorrência de quebra de resistência tem sido registrada logo após o lançamento de novas cultivares desenvolvidas para a região. Entre as causas de quebra de resistência está incluída a capacidade do fungo de desenvolver novos patótipos rapidamente. Uma amostra de 479 isolados monospóricos de $M$. oryzae foi obtida e testada no conjunto internacional de cultivares diferenciadoras de raças de brusone. As coletas de isolados foram feitas em pequenos viveiros usados como armadilhas de brusone e em locais ao acaso de campos vizinhos. A análise de 250 isolados de $M$. oryzae obtidos em três viveiros armadilha detectou a presença de 45 raças internacionais pertencentes a sete grupos de patótipos (IA-IG). Nos isolados testados, 61 patótipos de $M$. oryzae pertencentes a todos os grupos exceto o grupo IH foram detectados. As novas áreas de arroz irrigado do Vale do Rio Araguaia apresentam a maior diversidade de patótipos de M. oryzae descrita até o momento no Brasil.
\end{abstract}

Termos para indexação: Pyricularia, patogenicidade, patótipo, raça.

\section{Introduction}

Irrigated rice accounts for approximately $70 \%$ of the rice produced in Brazil. New commercial irrigated rice fields have been installed in the last 25 years in the Araguaia River Valley, state of Tocantins, Central Brazil, and blast disease is the most important problem for rice production in the area.
The blast-causing fungus Pyricularia grisea (Cooke) Sacc., an anamorph of Magnaporthe oryzae (Hebert) Barr is a yield-limiting factor for irrigated and upland rice. Fungicide control of rice blast is not cost effective. Breeding programs for blast resistance have developed numerous resistant cultivars. However, due to break of resistance, the useful lifespan of commercial cultivars has been short in blast-prone areas. In the Araguaia

Pesq. agropec. bras., Brasília, v.45, n.3, p.252-260, mar. 2010 
River Valley, resistance breakdown has been recorded after only one or two years of cultivar release.

Causes of resistance breakage are generally attributed to the capacity of the fungus to rapidly develop new pathotypes. The fungal genome is able to change, so that new recombinants or mutants can rapidly increase in frequency in the population and overcome the resistance genes present in new cultivars. The knowledge of the genetic diversity and prevalence of the physiological races of $M$. oryzae in production areas is an important step for devising strategies to develop new resistant cultivars.

Previous research on $M$. oryzae racial diversity on irrigated rice fields in Brazil usually showed narrow pathotype diversity. Prabhu et al. (2002) studied $53 \mathrm{M}$. oryzae isolates collected during the 1998/1999 growing season from two irrigated rice varieties planted on nine different fields located in the new rice irrigated fields of Central Brazil (Lagoa da Confusão and Dueré, state of Tocantins). They have identified only five $M$. oryzae races belonging to just one pathotype group (IB). Filippi et al. (2001) studied 87 M. oryzae isolates collected in the Metica 1 variety in the 1996/1997 growing season in Central Brazil. The isolates were collected from two fields in Formoso do Araguaia and two in Lagoa da Confusão. They have identified eight $M$. oryzae races belonging to five pathotype groups (IA, IB, ID, IG and II-1). Other studies on racial diversity of $M$. oryzae infecting irrigated rice in Brazil also did not detect extensive diversity. In Southern Brazil, Maciel et al. (2004) studied 85 M. oryzae isolates from irrigated rice collected in several commercial varieties grown in the state of Rio Grande do Sul. Upon evaluating the interaction phenotype based on the classification of the reactions as compatible or incompatible, they have identified $26 \mathrm{M}$. oryzae races belonging to just one pathotype group (IA). However, pathotype diversity in this region over periods of seven to ten years has been recorded, characterizing pathogen physiological variation (Ribeiro, 1980; Ribeiro \& Terres, 1987).

Contrasting with these results, a first indication of possible high levels of racial diversity of $M$. oryzae in Central Brazil was reported by Garrido (2001). As part of a study of the pathogen population structure over three years, he tested ten M. oryzae isolates from just one irrigated rice variety (Metica 1) planted in one field in Formoso do Araguaia, state of Tocantins, during the 1999 growing season. He identified five races belonging to five pathotype groups, indicating broad pathotype diversity in this region. The study also provided evidence that resistance breakdown in Central Brazil could be attributed to high pathotype diversity of $M$. oryzae. The high genetic diversity of the fungus was corroborated by molecular analysis with microsatellite markers of 432 isolates collected in the area (Garrido, 2001). A previous diversity study of $M$. oryzae isolates had already pointed out the higher genetic diversity of isolates from irrigated rice fields of Central Brazil in comparison to isolates from Southern Brazil (Brondani et al., 2000).

The objective of the present work was to detect and estimate the frequency of $M$. oryzae physiological races in irrigated rice production areas of Central Brazil, and to verify the existence of hot spots for M. oryzae racial diversity.

\section{Materials and Methods}

Samples of plants infected with $M$. oryzae and showing symptoms of rice blast were collected in the most important irrigated rice producing areas of the Araguaia River Valley, state of Tocantins, Brazil, during the 2007/2008 growing season, in the neighboring municipalities of Lagoa da Confusão (LC), Dueré and Formoso do Araguaia (FA) (Figure 1). This area is characterized by low altitude $(200 \mathrm{~m})$, tropical climate, and is located between coordinates $10^{\circ} 45^{\prime} 00^{\prime \prime} \mathrm{S}$ and $11^{\circ} 53^{\prime} 00^{\prime \prime} \mathrm{S}$, and $49^{\circ} 49^{\prime} 00^{\prime \prime} \mathrm{W}$ and $49^{\circ} 25^{\prime} 00^{\prime \prime} \mathrm{W}$. Sampling was done in: a, three blast nurseries, with samples of diseased plants obtained from equal sized areas (FA-1, FA-2 and LC); and b, "scattered" sampling obtained from random sites in the commercial fields.

The blast nurseries were planted with 17 rice varieties and lines covering 5,500 $\mathrm{m}^{2}$ each (Figure 1). These areas worked as "blast traps", since the host diversity could increase the probability of recovering different races of the pathogen in the area. Two blast traps were located in Formoso do Araguaia (FA-1 and FA-2, approximately $20 \mathrm{~km}$ apart) and one in Lagoa da Confusão (LC, approximately $110 \mathrm{~km}$ from FA-1 and FA-2), each surrounded by extensive commercial rice fields. Comparison of racial distribution between FA-1, FA-2 and LC was performed in order to provide an estimate of racial variability in the region based on isolate collections made on small areas. 
The "scattered" sampling of commercial fields was done in random sites in commercial fields, planted with nine rice cultivars, and scattered in the municipalities Lagoa da Confusão, Dueré and Formoso do Araguaia, in order to provide a view of the racial variability on larger commercial areas (Figure 1).

Biological samples were restricted to leaves and panicles showing typical blast symptoms collected from rice plants in the field during the vegetative and reproductive stages of the crop. Sampled plants were GPS located during sampling. One leaf or panicle showing blast symptoms was sampled per plant and one monosporic culture was obtained from a selected lesion. Samples were obtained from plants at least $3 \mathrm{~m}$ apart in the trap nurseries and at least $10 \mathrm{~m}$ apart in the scattered sites. The samples were kept in a refrigerator, at $4^{\circ} \mathrm{C}$, until single spores were isolated for culture and analysis.

Only one monosporic culture was maintained from a selected lesion observed in a leaf or panicle sample.
Each isolate, therefore, refers to only one specific plant showing blast symptoms in the field. Prior to spore isolation, plant and panicle samples without cleaning were placed in a humid chamber and incubated in B.O.D. at $25^{\circ} \mathrm{C}$ for 24 hours to stimulate sporulation. With the help of an optical microscope, a conidium from the sporulated lesions was transferred to a sterile Petri dish containing an agar-water culture medium at $2 \%$. The dish containing the conidium in water-agar medium was incubated in B.O.D. at $25^{\circ} \mathrm{C}$ for 48 hours for germination. With the help of an optical microscope and using a scalpel, individual germinated conidia were isolated and transferred to PDA culture medium with the addition of $250 \mathrm{mg}$ of the antibiotic ampicillin. Each monosporic isolate was then incubated for growth on PDA at $25^{\circ} \mathrm{C}$. Discs of culture medium and mycelia of established cultures of monosporic isolates were transferred to Petri dishes containing PDA medium under aseptic conditions and incubated at $25^{\circ} \mathrm{C}$. On the $12^{\text {th }}$ day of growth, the monosporic isolates were

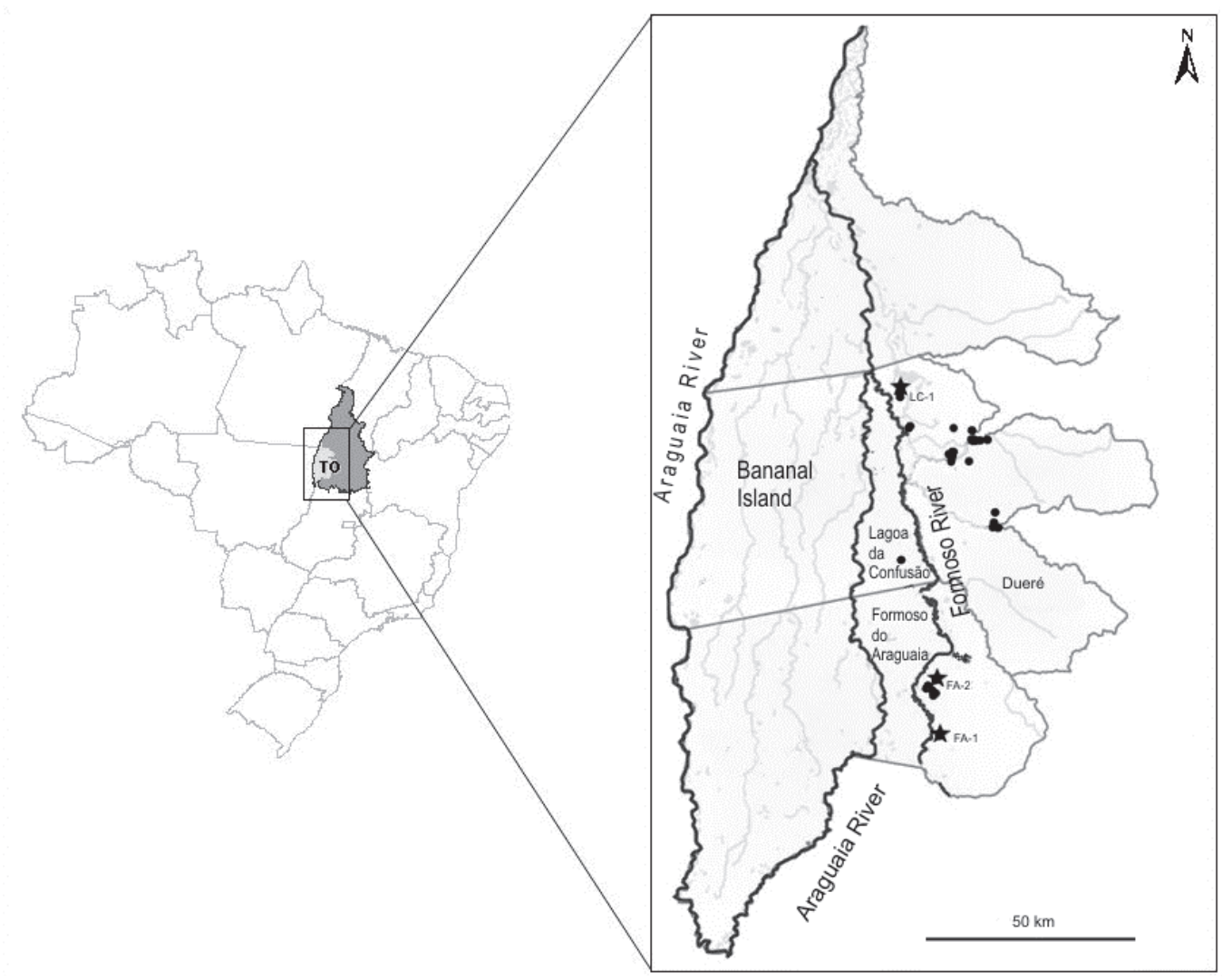

Figure 1. Irrigated rice fields sampled for M. oryzae pathotype diversity in the Araguaia River Valley, state of Tocantins, Central Brazil. Stars represent blast trap nurseries (FA-1, FA-2, LC) and dots, the scattered sites of commercial fields in the nearby area along the region where rice is produced. 
stressed in order to stimulate abundant sporulation. The superficial mycelium was scraped using a sterile steel rod and the dishes were kept opened, covered with a thin sterile cloth, in a growth chamber at $25^{\circ} \mathrm{C}$ and with continuous fluorescent light for 48 hours and a relative air humidity of $70 \%$. After sporulation, each dish was washed with $20 \mathrm{~mL}$ of sterile distilled water, the suspension obtained was filtered with a sterile cloth and the spores were quantified in a Neubauer chamber. Inoculum suspension concentration was adjusted to $3 \times 10^{5}$ conidia $\mathrm{mL}^{-1}$ prior to inoculation.

The identification of the $M$. oryzae physiological races was carried out through visual observation of the interaction phenotype of each monosporic isolate with a set of eight rice cultivars internationally used for differentiating races of $M$. oryzae (Atkins et al., 1967). The differential set is composed of cultivars Raminad Str-3, Zenith, NP-125, Usen, Dular, Kanto 51, Sha-tiao-tsao and Caloro. Each cultivar was sown on $38 \times 28 \times 7 \mathrm{~cm}$ plastic trays, filled with $3.5 \mathrm{~L}$ of autoclaved Plantmax (Eucatex, São Paulo, Brazil) substrate. Each line was replicated three times on each tray. Fifteen days after seedling emergence, the plants were fertilized with $3 \mathrm{~g}$ of urea $(45 \% \mathrm{~N})$ per tray, in order to predispose the seedlings to $M$. oryzae infection. The temperature was kept at $25 \pm 2^{\circ} \mathrm{C}$ throughout the experiment. Inoculation was performed 25 days after seedling emergence with a manual sprayer, homogeneously spraying approximately $20 \mathrm{~mL}$ of the spore suspension per tray. Immediately after the inoculation, the trays were incubated in a dark and humid chamber $(>95 \%)$ for 24 hours. After this period, the trays were transferred to a growth chamber at $25^{\circ} \mathrm{C}$ with $70 \%$ humidity for seven days and 12 hours of photoperiod.

Interaction phenotype was evaluated seven days after the inoculation, based on a scale of 1 to 9 (Leung et al., 1988). A differential cultivar was considered resistant $(\mathrm{R})$ when it received an interaction phenotype grade equal to or less than 3, and susceptible (S) when the grade was equal or greater than 4 . The identification of the $M$. oryzae races followed the standard international race key numbers (Ling \& Ou, 1969). In this system, the differentials are each assigned a letter (A to $\mathrm{H}$ ), according to a specific order of the differential varieties - Raminad Str-3 (A), Zenith (B), NP-125 (C), Usen (D), Dular (E), Kanto $51(\mathrm{~F})$, Sha-tiao-tsao $(\mathrm{G})$ and Caloro $(\mathrm{H})$ - and the race numbers are assigned according to the interaction phenotype observed. Therefore, an isolate with an interaction compatible (S) with cultivar Raminad Str-3 and incompatible $(\mathrm{R})$ with all other seven differential cultivars (i.e., SRRRRRRR) was classified as belonging to race IA-128, while an isolate with incompatible reaction with all eight differentials (i.e., RRRRRRRR) was classified as belonging to race II-1.

Race assignment of all M. oryzae isolates was initially performed for collections made in the three trap nurseries located in Formoso do Araguaia (FA-1 and FA-2) and Lagoa da Confusão (LC). The number of races on each nursery was computed manually after evaluation of the interaction phenotype. The race group variation per trap nursery was estimated by computing the total number of race groups observed in a specific location. Race richness (\%) per trap nursery was computed as a percentage of race groups divided by the number of monosporic isolates sampled in each nursery. Pathotype diversity was estimated for each trap nursery using the Shannon-Wiever diversity index (H') (Andrivon \& De Vallavieille-Pope, 1993).

Confidence intervals were calculated according to procedures described by Grünwald et al. (2003). Pathotype evenness, or how the abundance of pathotypes is distributed in the three trap nurseries, was estimated according to index 5 (E5), described by Ludwig \& Reynolds (1988).

To test if the racial profile of $M$. oryzae of one trap nursery was different from the expected, the observed frequencies of all races detected in one nursery were compared with the expected frequencies for a sample of the same size from the population database (FA-1 + FA-2 + LC), assuming the isolates obtained in the three trap nurseries as part of the same population. Expected frequencies were estimated by re-sampling such population $(10,000$ bootstrap iterations) using Resampling Stats v.3.0 software (Resampling Stats, 2006), in a randomized goodness-of-fit test. Pathotype complexity on the trap nurseries and estimates of confidence intervals were estimated by the average number of virulence alelles per pathotype $\left(\mathrm{C}_{\mathrm{p}}\right)$ and the average number of virulence alleles per isolate $\left(C_{i}\right)$, as described by Andrivon \& De Vallavieille-Pope (1993). Expected pathotype frequencies were assumed as the threshold values for considering pathotype frequencies observed in the field within the range that could be expected by chance.

A similar procedure was used to verify if $M$. oryzae isolates collected from scattered rice fields would have 
the observed racial profile different from the expected, when compared with the expected frequencies for a sample of the same size from the population database (479 isolates), assuming the isolates obtained from scattered fields as part of the overall population (trap nurseries + scattered fields). Expected frequencies and levels of significance were estimated as described above.

\section{Results and Discussion}

A total of $479 \mathrm{M}$. oryzae monosporic isolates were obtained from new areas of irrigated rice production located in the Araguaia River Valley, state of Tocantins, Central Brazil. The observed M. oryzae pathotype variation based on sampling of blast diseased plants identified on trap nurseries was very high. Up to 27 different international races of the pathogen (e.g., LC) could be identified in just one location (Table 1). The isolates belonged to seven out of nine pathotype groups (IA, IB, IC, ID, IE, IF, IG). The smallest number of races was detected in FA-2. Pathotype richness varied from 25 to $30 \%$ in the three trap nurseries, i.e., one out of four isolates collected in the trap nurseries was assigned to a different race of the pathogen. Comparisons of pathotype diversity observed on the three trap nurseries indicated similar values for FA-1 and LC, and smaller diversity for FA-2. The values of Shannon-Wiever's H' for the three trap nurseries were 2.84, 2.20 and 2.83 for FA-1, FA-2 and LC respectively. Estimates of evenness were also higher for FA-1 and LC (0.871 and 0.859), and smaller for FA-2 (0.762). Confidence intervals indicated that there are no significant differences between the pathotype diversity observed on trap nurseries FA-1 and LC ( $>00.05)$, but sampling diversity was significantly smaller on FA-2. A total of 45 different races belonging to seven pathotype groups could be identified in the three sites, corroborating the observation that pathotype richness and diversity is very high in the region.

There were instances of detection of a specific pathotype on one blast trap which were not found in others. The number of pathotype groups detected varied from four on FA-2 to seven on LC (Table 1). These results reveal abundant racial diversity of the pathogen in small areas sampled in this region during the same growing season. The three trap nurseries showed a similar profile of $M$. oryzae pathotype distribution (Figure 2). The most frequent races in a sampled nursery were usually the most common ones on the other blast traps. However, the magnitude of frequency values sometimes differed (Table 2). Comparisons of the observed frequencies of all races detected on a trap nursery and the expected frequency of the races, estimated by re-sampling the database by means of a bootstrap procedure, showed that the observed pathotype frequency was quite often smaller than the value expected by chance alone. This indicated that the majority $(67.4 \%)$ of the observed pathotype frequency on the three small areas (FA-1, FA-2 and LC) was within the range of what would be expected by chance when it was assumed that they all belonged to the same pathogen population. This data indicated that the samples taken on FA-1, FA-2 and LC belong to the same $M$. oryzae population. Estimates of average number of virulence alelles per pathotype $\left(\mathrm{C}_{\mathrm{p}}\right)$ were 2.65, 2.17 and 2.74 for FA-1, FA-2 and LC respectively. There was no difference $(p<0.5)$ between $\mathrm{C}_{\mathrm{p}}$ values observed on FA-1, FA-2 and LC. However, the average number of virulence alleles per isolate $\left(\mathrm{C}_{\mathrm{i}}\right)$ was significantly smaller on FA-2 (4.50) when compared to FA-1 (6.62) and LC (6.85).

Considering all the $250 \mathrm{M}$. oryzae isolates from three trap nurseries, a total of 45 international M. oryzae races were identified, belonging to seven physiological race groups (IA-IG), with an overall pathotype richness of

Table 1. Magnaporthe oryzae pathotype diversity based on samples collected in blast trap nurseries in three locations in the municipalities of Formoso do Araguaia (FA-1 and FA-2) and Lagoa da Confusão (LC), and from scattered fields in the vicinity of the trap nurseries in the Araguaia River Valley, state of Tocantins, Central Brazil.

\begin{tabular}{|c|c|c|c|c|c|c|}
\hline \multirow{2}{*}{ Parameter } & \multicolumn{4}{|c|}{ Trap nurseries } & \multirow[t]{2}{*}{ Scattered fields } & \multirow[t]{2}{*}{ Total } \\
\hline & FA-1 & FA-2 & $\mathrm{LC}$ & Total & & \\
\hline Isolates & 85 & 70 & 95 & 250 & 229 & 479 \\
\hline M. oryzae races & 26 & 18 & 27 & 45 & 33 & 61 \\
\hline Pathotype groups & $\begin{array}{l}\text { IA, IB, IC, ID, } \\
\text { IE }\end{array}$ & IA, IB, IC, ID & $\begin{array}{l}\text { IA, IB, IC, ID, } \\
\text { IE, IF, IG }\end{array}$ & $\begin{array}{l}\text { IA, IB, IC, ID, } \\
\text { IE, IF, IG }\end{array}$ & $\begin{array}{c}\text { IA, IB, IC, ID, IE, } \\
\text { IF, IG, II-1 }\end{array}$ & $\begin{array}{c}\text { IA, IB, IC, ID, IE, IF, } \\
\text { IG, II-1 }\end{array}$ \\
\hline Pathotype richness (\%) & 31 & 26 & 28 & 18 & 14 & 13 \\
\hline
\end{tabular}


$18 \%$ (Table 1). This is the first report of the occurrence of the majority of $M$. oryzae pathotype groups in a single location in Brazil during the same growing season and in such small sampling areas. This indicates that the new irrigated rice producing areas of Central Brazil are hot spots for $M$. oryzae pathotype diversity.

Racial diversity of $M$. oryzae isolates from scattered collections made in commercial fields around the trap nurseries was also estimated. Based on an independent sample of 229 M. oryzae isolates, up to 33 different international races of the pathogen belonging to eight different pathotype groups were identified (Table 1). Pathotype richness was of approximately $14 \%$, similar to that estimated for the sum of data collected in the three trap nurseries. The majority $(84 \%)$ of the observed racial frequency in the scattered fields was within the range of what would be expected by chance when it was assumed that they all belonged to the same pathogen population (Table 2). This indicated that the samples taken from scattered fields and from the trap nurseries belong to the same $M$. oryzae population.

The use of trap nurseries was efficient for sampling the pathotype diversity from scattered collections in the field. It was observed, however, that even with a slightly smaller sample size of 229 isolates, the scattered collection allowed for the identification of 16 additional pathotypes and one additional racial group (II-1) (Table 1). Whereas the blast traps were planted with 17 rice cultivars, the scattered sampling only included nine cultivars. Scattered sampling is, therefore, a recommended procedure to estimate pathotype diversity when compared to trap nurseries.

Taking into account all the data collected from irrigated rice fields of the Araguaia River Valley, Tocantins state, Central Brazil (479 isolates), M. oryzae isolates belonging to all but one (IH) physiological race group were detected (Table 1). A total of 61 international M. oryzae races were identified during the same season. The ten most prevalent pathotypes, making up $72 \%$ of the isolates, were races IA-1, IC-1, ID-1, IA-65, ID-9, IA-33, IB-1, IA-41, IA-9 and IB-33. The new areas of irrigated rice in Central Brazil have the highest diversity of $M$. oryzae pathotype detected so far in the country. This might explain the short lifespan of resistant rice cultivars in the region, since resistance breakdown usually occurs shortly after the release of new cultivars. As a consequence, in depth discussion of strategies to develop cultivars with long lasting resistance for this region is necessary.

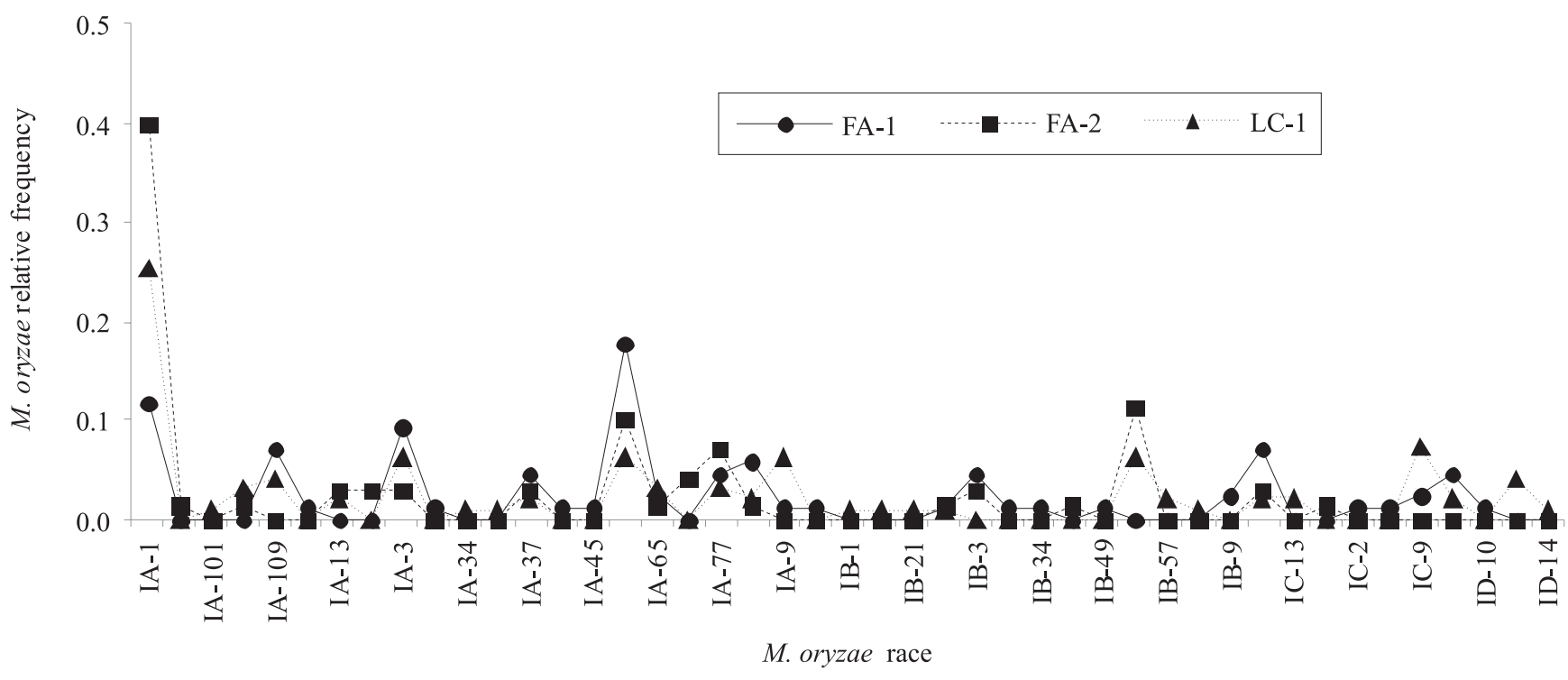

Figure 2. Magnaporthe oryzae pathotype profile of isolates collected in blast trap nurseries in three localities in the municipalities of Formoso do Araguaia (FA-1 and FA-2) and Lagoa da Confusão (LC), Araguaia River Valley, Tocantins state, Central Brazil. 
Table 2. Observed and expected relative frequencies of Magnaporthe oryzae pathotypes based on samples collected in blast trap nurseries in Formoso do Araguaia (FA-1 and FA-2) and Lagoa da Confusão (LC), and from scattered fields in their vicinity, Araguaia River Valley, state of Tocantins, Central Brazil.

\begin{tabular}{|c|c|c|c|c|c|c|c|c|}
\hline \multirow[t]{2}{*}{ Race } & \multicolumn{2}{|c|}{ FA-1 } & \multicolumn{2}{|c|}{ FA-2 } & \multicolumn{2}{|c|}{$\mathrm{LC}$} & \multicolumn{2}{|c|}{ Scattered fields } \\
\hline & Observed & Expected & Observed & Expected & Observed & Expected & Observed & Expected \\
\hline IA-1 & 0.118 & 0.248 & 0.400 & 0.247 & 0.253 & 0.249 & 0.079 & 0.167 \\
\hline IA-10 & 0.000 & 0.004 & 0.014 & 0.004 & 0.000 & 0.004 & 0.000 & 0.002 \\
\hline IA-101 & 0.000 & 0.004 & 0.000 & 0.004 & 0.011 & 0.004 & 0.000 & 0.002 \\
\hline IA-105 & 0.000 & 0.016 & 0.014 & 0.016 & 0.032 & 0.017 & 0.000 & 0.008 \\
\hline IA-109 & 0.071 & 0.040 & 0.000 & 0.040 & 0.042 & 0.040 & 0.000 & 0.021 \\
\hline IA-121 & 0.012 & 0.004 & 0.000 & 0.004 & 0.000 & 0.004 & 0.000 & 0.002 \\
\hline IA-13 & 0.000 & 0.015 & 0.029 & 0.016 & 0.021 & 0.016 & 0.000 & 0.008 \\
\hline IA-25 & $-^{(1)}$ & - & - & - & - & - & 0.004 & 0.002 \\
\hline IA-3 & 0.000 & 0.008 & 0.029 & 0.009 & 0.000 & 0.008 & 0.000 & 0.004 \\
\hline IA-33 & 0.094 & 0.065 & 0.029 & 0.064 & 0.063 & 0.064 & 0.026 & 0.046 \\
\hline IA-34 & 0.012 & 0.004 & 0.000 & 0.004 & 0.000 & 0.004 & 0.000 & 0.002 \\
\hline IA-35 & 0.000 & 0.004 & 0.000 & 0.004 & 0.011 & 0.004 & 0.000 & 0.002 \\
\hline IA-37 & 0.000 & 0.004 & 0.000 & 0.004 & 0.011 & 0.005 & 0.000 & 0.002 \\
\hline IA-41 & 0.047 & 0.032 & 0.029 & 0.032 & 0.021 & 0.032 & 0.044 & 0.038 \\
\hline IA-45 & 0.012 & 0.004 & 0.000 & 0.004 & 0.000 & 0.004 & 0.000 & 0.002 \\
\hline IA-57 & 0.012 & 0.004 & 0.000 & 0.004 & 0.000 & 0.004 & 0.000 & 0.002 \\
\hline IA-65 & 0.176 & 0.111 & 0.100 & 0.113 & 0.063 & 0.111 & 0.013 & 0.066 \\
\hline IA-73 & 0.024 & 0.024 & 0.014 & 0.024 & 0.032 & 0.023 & 0.004 & 0.015 \\
\hline IA-77 & 0.000 & 0.012 & 0.043 & 0.012 & 0.000 & 0.012 & 0.000 & 0.006 \\
\hline IA-81 & - & - & - & - & - & - & 0.004 & 0.002 \\
\hline IA-9 & 0.047 & 0.048 & 0.071 & 0.048 & 0.032 & 0.048 & 0.022 & 0.035 \\
\hline IA-97 & 0.059 & 0.032 & 0.014 & 0.032 & 0.021 & 0.032 & 0.004 & 0.019 \\
\hline IB-1 & 0.012 & 0.028 & 0.000 & 0.028 & 0.063 & 0.027 & 0.061 & 0.044 \\
\hline IB-17 & 0.012 & 0.004 & 0.000 & 0.004 & 0.000 & 0.004 & 0.000 & 0.002 \\
\hline IB-21 & 0.000 & 0.004 & 0.000 & 0.004 & 0.011 & 0.004 & 0.000 & 0.002 \\
\hline IB-26 & 0.000 & 0.004 & 0.000 & 0.004 & 0.011 & 0.004 & 0.000 & 0.002 \\
\hline IB-3 & 0.000 & 0.004 & 0.000 & 0.004 & 0.011 & 0.004 & 0.000 & 0.002 \\
\hline IB-33 & 0.012 & 0.012 & 0.014 & 0.012 & 0.011 & 0.012 & 0.048 & 0.029 \\
\hline IB-34 & - & - & - & - & - & - & 0.004 & 0.002 \\
\hline IB-41 & 0.047 & 0.024 & 0.029 & 0.024 & 0.000 & 0.024 & 0.026 & 0.026 \\
\hline IB-49 & - & - & - & - & - & - & 0.004 & 0.002 \\
\hline IB-5 & 0.012 & 0.004 & 0.000 & 0.004 & 0.000 & 0.004 & 0.000 & 0.002 \\
\hline IB-57 & 0.012 & 0.004 & 0.000 & 0.004 & 0.000 & 0.004 & 0.009 & 0.006 \\
\hline IB-58 & 0.000 & 0.004 & 0.014 & 0.004 & 0.000 & 0.004 & 0.000 & 0.002 \\
\hline IB-9 & 0.012 & 0.004 & 0.000 & 0.004 & 0.000 & 0.004 & 0.004 & 0.004 \\
\hline IC-1 & 0.000 & 0.056 & 0.114 & 0.056 & 0.063 & 0.056 & 0.201 & 0.125 \\
\hline IC-13 & 0.000 & 0.008 & 0.000 & 0.008 & 0.021 & 0.008 & 0.000 & 0.004 \\
\hline IC-17 & 0.000 & 0.004 & 0.000 & 0.004 & 0.011 & 0.004 & 0.004 & 0.004 \\
\hline IC-2 & - & - & - & - & - & - & 0.004 & 0.002 \\
\hline IC-4 & - & - & - & - & - & - & 0.004 & 0.002 \\
\hline IC-9 & 0.024 & 0.008 & 0.000 & 0.008 & 0.000 & 0.008 & 0.017 & 0.013 \\
\hline ID-1 & 0.071 & 0.040 & 0.029 & 0.040 & 0.021 & 0.040 & 0.192 & 0.113 \\
\hline ID-10 & - & - & - & - & - & - & 0.004 & 0.002 \\
\hline ID-13 & - & - & - & - & - & - & 0.026 & 0.012 \\
\hline ID-14 & - & - & - & - & - & - & 0.013 & 0.006 \\
\hline ID-15 & 0.000 & 0.008 & 0.000 & 0.007 & 0.021 & 0.008 & 0.000 & 0.004 \\
\hline ID-2 & - & - & - & - & - & - & 0.004 & 0.002 \\
\hline ID-3 & 0.000 & 0.004 & 0.014 & 0.004 & 0.000 & 0.004 & 0.000 & 0.002 \\
\hline ID-4 & - & - & - & - & - & - & 0.009 & 0.004 \\
\hline ID-5 & 0.012 & 0.004 & 0.000 & 0.004 & 0.000 & 0.004 & 0.004 & 0.004 \\
\hline ID-6 & - & - & - & - & - & - & 0.004 & 0.002 \\
\hline ID-7 & 0.012 & 0.004 & 0.000 & 0.004 & 0.000 & 0.004 & 0.000 & 0.002 \\
\hline ID-9 & 0.024 & 0.037 & 0.000 & 0.036 & 0.074 & 0.036 & 0.083 & 0.055 \\
\hline IE-1 & 0.047 & 0.023 & 0.000 & 0.024 & 0.021 & 0.023 & 0.013 & 0.019 \\
\hline IE-2 & - & - & - & - & - & - & 0.009 & 0.004 \\
\hline IE-3 & 0.012 & 0.004 & 0.000 & 0.004 & 0.000 & 0.004 & 0.000 & 0.002 \\
\hline IF-1 & 0.000 & 0.016 & 0.000 & 0.015 & 0.042 & 0.015 & 0.022 & 0.019 \\
\hline IF-3 & & & & & & & 0.004 & 0.002 \\
\hline IF-4 & - & - & - & - & - & - & 0.013 & 0.006 \\
\hline IG-1 & 0.000 & 0.004 & 0.000 & 0.004 & 0.011 & 0.004 & 0.000 & 0.002 \\
\hline II-1 & - & - & - & - & - & - & 0.009 & 0.004 \\
\hline
\end{tabular}

${ }^{(1)}$ Not observed. 
The disease usually causes more constraints to rainfed upland rice production than to irrigated rice in Brazil (Ribeiro, 1980). Perhaps for this reason there have been more reports on pathotype diversity of $M$. oryzae infecting rainfed upland rice. There is great variation on the number of isolates, number of locations, number of host varieties and number of growing seasons sampled by different studies (Table 3). Also, the sampling method is not always the same and, at times, not described. Nonetheless, the levels of pathotype diversity observed in irrigated rice of the Araguaia River Valley are higher than any of the estimates obtained with samples from irrigated and rainfed upland rice in Brazil so far. It must be mentioned that the pathotype diversity of some regions was recorded over periods of seven (Ribeiro \& Terres, 1987) and ten years (Ribeiro, 1980), based on sampling of diverse host genotypes over several sites.

The $M$. oryzae pathotype diversity detected in the Araguaia River Valley's irrigated rice fields is similar to other described hot spots of M. oryzae diversity used as breeding nurseries for selection for resistance to $M$. oryzae in other countries. In Colombia, $151 \mathrm{M}$. oryzae isolates from 15 infected rice cultivars have been classified into 39 pathotypes representing all nine pathotype groups in Santa Rosa, eastern Colombia (Correa-Victoria \& Zeigler, 1993), a site assumed to contain more than five times the pathotype range typically found in the United States (Levy et al., 1993).
Other hot spot areas include Pattambi, Kerala State, Southern India, several locations in West Africa (Singh et al., 2000), and the Yuan'an County, Hubei Province (Hubei site), China (Li et al., 2008).

The implications of high $M$. oryzae pathotype diversity for breeding for durable resistance are manyfold. Recent efforts by breeding programs aiming at the development of cultivars for the Araguaia River Valley's region have capitalized on the use of natural infection on breeding sites in other areas of the country to select for blast resistance. It seems that the pathotype diversity at these sites has not been adequate for durable resistance selection for the irrigated areas of Central Brazil, since, as mentioned before, resistance breakdown in this region has been reported to occur shortly after cultivar release. Breeding efforts for this region should, therefore, consider the use of breeding stations located in hot spots for blast pathotype diversity in the Araguaia River Valley's region.

It should be pointed out that, although rice cultivation is new in the region, upland rice cultivation has been traditional in all Central Brazil. Blast disease has been described in alternative grass host species and even in Oryza glumaepatula and other wild rice species populations, native to the area. Assessing pathotype diversity of blast populations should, therefore, receive in depth attention in order to evaluate the role of pathogen migration from crop systems, alternative

Table 3. Reported parameters of $M$. oryzae pathotype diversity sampled on irrigated and rainfed upland rice in Brazil based on the international differential set.

\begin{tabular}{|c|c|c|c|c|c|c|}
\hline Rice varieties & Isolates & Pathotypes & Pathotype groups & Locations & $\begin{array}{c}\text { Growing } \\
\text { seasons }\end{array}$ & Authors \\
\hline \multicolumn{7}{|c|}{ Irrigated rice } \\
\hline 2 & 53 & 9 & $1(\mathrm{IB})$ & 9 & 1 & Prabhu et al. (2002b) \\
\hline 1 & 87 & 8 & $5(\mathrm{IA}, \mathrm{IB}, \mathrm{ID}, \mathrm{IG}, \mathrm{II}-1)$ & 4 & 1 & Fillipi et al. (2002) \\
\hline Several & 85 & 26 & 1 (IA) & Several & 6 & Maciel et al. (2004) \\
\hline Several & 124 & 26 & 9 (IA-IH, II-1) & Several & 10 & Ribeiro (1980) \\
\hline Several & 127 & 24 & 9 (IA-IH, II-1) & Several & 7 & Ribeiro \& Terres (1987) \\
\hline 1 & 10 & 5 & 5 (IA-IB, ID, IH, II-1) & 1 & 1 & Garrido (2001) \\
\hline \multicolumn{7}{|c|}{ Rainfed upland rice } \\
\hline 10 & 72 & 16 & $3(\mathrm{IA}-\mathrm{IC})$ & 3 & 3 & Fillipi \& Prabhu (2001) \\
\hline 8 & 77 & 13 & 5 (IA-IF) & 1 & 5 & Prabhu et al. (2003) \\
\hline 14 & 85 & 11 & 4 (IB-ID, IG) & 1 & 5 & Prabhu et al. (2002a) \\
\hline Several $^{(1)}$ & 138 & 14 & 3 (IA-IC) & 15 & 1 & Cornelio et al. (2003) \\
\hline 1 & 170 & 25 & 7 (IA-IG) & 3 & 2 & Araújo et al. (2005) \\
\hline 1 & 139 & 38 & 6 (IA-IC, IE-IG) & 4 & 2 & Araújo et al. (2005) \\
\hline Several & 23 & 20 & 8 (IA-IG, II-1) & Several & 10 & Malavolta \& Souza (1992) \\
\hline Several & 71 & 21 & 7 (IB-IG, II-1) & Several & 3 & Malavolta et al. (2009) \\
\hline 8 & 306 & 30 & $8(\mathrm{IA}-\mathrm{IH})$ & 8 & 2 & Silva et al. (2007) \\
\hline
\end{tabular}

\footnotetext{
${ }^{(1)}$ Mostly lowland varieties.
} 
hosts and wild species, in order to develop cultivars with durable resistance for this region.

\section{Conclusions}

1. The irrigated rice fields of the Araguaia River Valley, state of Tocantins, Brazil, are hot spots for Magnaporthe oryzae pathotype diversity.

2. Hot spots in this area can be used as blast nurseries for breeding programs.

3. Scattered sampling is more efficient than sampling in blast trap nurseries to determine Magnaporthe oryzae pathotype diversity.

\section{Acknowledgements}

To Conselho Nacional de Desenvolvimento Científico e Tecnológico and Empresa Brasileira de Pesquisa Agropecuária, for the financial and logistic support; to Eutania Canjão and Azelma Correia Fontana Cunha, for laboratory technical assistance.

\section{References}

ANDRIVON, D.; DE VALLAVIEILLE-POPE, C. Racial diversity and complexity in regional populations of Erysiphe graminis f. sp. hordei in France over a 5-year period. Plant Pathology, v.42, p.443-464, 1993.

ATKINS, J.G.; ROBERT, A.L.; ADAIR, C.R.; GOTO, K.; KOZAKA, T.; YANAGIDA, R.; YAMADA, M.; MATSUMOTO, $\mathrm{S}$. An international set of rice varieties for differentiating races of Pyricularia oryzae. Phytopathology, v.57, p.297-301, 1967.

BRONDANI, C.; BRONDANI, R.P.V.; GARRIDO, L. da R.; FERREIRA, M.E. Development of microsatellite markers for genetic analysis of Magnaporthe grisea. Genetics and Molecular Biology, v.23, p.753-762, 2000.

CORREA-VICTORIA, F.J.; ZEIGLER, R.S. Pathogenic variability in Pyricularia grisea at a rice blast "hot spot" breeding site in eastern Colombia. Plant Disease, v.77, p.1029-1035, 1993.

FILIPPI, M.C.; PRABHU, A.S. Phenotypic virulence analysis of Pyricularia grisea isolates from Brazilian upland rice cultivars. Pesquisa Agropecuária Brasileira, v.36, p.27-35, 2001.

GARRIDO, L.R. Identificação, desenvolvimento e uso de marcadores de regiões hipervariáveis do genoma de Magnaphorte grisea na análise da estrutura de populações do patógeno infectando populações de arroz (Oryza sativa). 2001. 193p. Tese (Doutorado) - Universidade de Brasília, Brasília.

GRÜNWALD, N.J.; GOODWIN, S.B.; MILGROOM, M.G.; FRY, W.E. Analysis of genotypic diversity data for populations of microorganisms. Phytopathology, v.93, p.738-746, 2003.

LEUNG, H.; BORROMEO, E.S.; BERNARDO, M.A.; NOTTEGHEM, J.L. Genetic analysis of virulence in the rice blast fungus Magnaporthe grisea. Phytopathology, v.78, p.1227-1233, 1988.

LEVY, M.; CORREA-VICTORIA, F.J.; ZEIGLER, R.S.; XU, S.; HAMER, J.E. Genetic diversity of the rice blast fungus in a disease nursery in Colombia. Phytopathology, v.83, p.1427-1433, 1993.

LI, Y.; WU, C.; XING, Y.; CHEN, H.; HE, Y. Dynamic QTL analysis for rice blast resistance under natural infection conditions. Australian Journal of Crop Science, v.2, p.73-82, 2008.

LING, K.C.; OU, S.H. Standardization of international race numbers of Pyricularia oryzae. Phytopathology, v.59, p.339-342, 1969.

LUDWIG, J.A.; REYNOLDS, J.F. Statistical ecology: a primer on methods and computing. New York: John Wiley \& Sons, 1988. 337p.

MACIEL, J.L.N.; RODRIGUES, P.C.S.; AVOZANI, O.A.; MORAES, M.G. Padrão molecular e de virulência de isolados de Pyricularia grisea do Estado do Rio Grande do Sul. Fitopatologia Brasileira, v.29, p.504-510, 2004.

PRABHU,A.S.;FILIPPI, M.C.;ARAÚJO,L.G.;FARIA, J.C. Genetic and phenotypic characterization of isolates of Pyricularia grisea from the rice cultivars Epagri 108 and 109 in the state of Tocantins. Fitopatologia Brasileira, v.27, p.566-573, 2002.

RESAMPLING STATS. Add in for Excel. Version 3.0. Arlington: Resampling Stats, 2006.

RIBEIRO, A.S. Prevalência de raças de Pyricularia oryzae Cav. no Rio Grande do Sul. Pesquisa Agropecuária Brasileira, v.15, p.175-182, 1980.

RIBEIRO, A.S.; TERRES, A.L.S. Variabilidade do fungo Pyricularia oryzae e sua relação com cultivares resistentes à brusone. Fitopatologia Brasileira, v.12, p.316-321, 1987.

SINGH, B.N.; JONES, M.P.; FOMBA, S.N.; SERE, Y.; SY, A.A.; AKATOR, K.; NGNINBEYIE, P.; AHN, S.W. Breeding for blast resistance in rice in West Africa. In: THARREAU, D.; LEBRUN, M.H.; TALBOT, N.J.; NOTTEGHEM, J.L. (Ed.). Advances in rice blast research. Dordrecht: Kluwer Academic Publishers, 2000. p.112-128. 